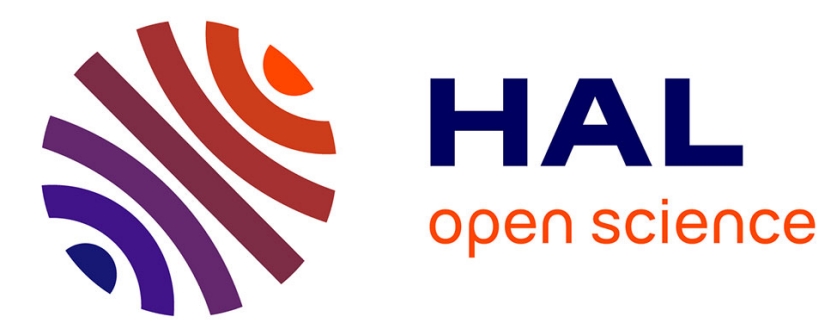

\title{
Rate Constants of the Reactions of O( 3 P) Atoms with Ethene and Propene over the Temperature Range 230-900 K
}

\author{
Julien Morin, Yuri Bedjanian, Manolis Romanias
}

\section{To cite this version:}

Julien Morin, Yuri Bedjanian, Manolis Romanias. Rate Constants of the Reactions of O( $3 \mathrm{P})$ Atoms with Ethene and Propene over the Temperature Range 230-900 K. International Journal of Chemical Kinetics, 2017, 49 (1), pp.53 - 60. 10.1002/kin.21056 . hal-01804117

\section{HAL Id: hal-01804117 https://hal.science/hal-01804117}

Submitted on 14 Jan 2022

HAL is a multi-disciplinary open access archive for the deposit and dissemination of scientific research documents, whether they are published or not. The documents may come from teaching and research institutions in France or abroad, or from public or private research centers.
L'archive ouverte pluridisciplinaire HAL, est destinée au dépôt et à la diffusion de documents scientifiques de niveau recherche, publiés ou non, émanant des établissements d'enseignement et de recherche français ou étrangers, des laboratoires publics ou privés. 


\title{
Rate Constants of the Reactions of $\mathrm{O}\left({ }^{3} \mathbf{P}\right)$ Atoms with Ethene and Propene over the Temperature Range 230 - $900 \mathrm{~K}$.
}

\author{
JULIEN MORIN, YURI BEDJANIAN*, MANOLIS N. ROMANIAS ${ }^{\dagger}$
}

Institut de Combustion, Aérothermique, Réactivité et Environnement (ICARE), CNRS and Université d'Orléans, 45071 Orléans Cedex 2, France

\begin{abstract}
The kinetics of the reactions of ethene and propene with triplet oxygen atoms have been studied over a wide temperature range, $\mathrm{T}=230-900 \mathrm{~K}$, using a low pressure $(\mathrm{P}=$ 1 Torr) flow tube reactor coupled with an electron impact ionization quadrupole mass spectrometer: $\mathrm{O}+\mathrm{C}_{2} \mathrm{H}_{4} \rightarrow$ products (1) and $\mathrm{O}+\mathrm{C}_{3} \mathrm{H}_{6} \rightarrow$ products (2). The rate constants of the title reactions were determined under pseudo-first order conditions, either monitoring the kinetics of $\mathrm{O}$-atom consumption in excess of alkene or alkene loss in excess of oxygen atoms. The temperature dependence of the rate constant of reaction $(1), k_{1}=8.64 \times 10^{-17} \mathrm{~T}^{1.70} \exp (-$ $206 / \mathrm{T}$ ) $\mathrm{cm}^{3}$ molecule $^{-1} \mathrm{~s}^{-1}$ (uncertainty of 20\%), was found to be in excellent agreement with multiple previous data that can be considered as a validation of the experimental approach. The measurements of the rate constant of the reaction of $\mathrm{O}$ atoms with propene, $k_{2}=3.65 \times 10^{-}$ ${ }^{18} \mathrm{~T}^{2.20} \exp (455 / \mathrm{T}) \mathrm{cm}^{3}$ molecule $\mathrm{s}^{-1}$ (uncertainty of $20 \%$ ), allowed to harmonize the results of previous low and high temperature measurements and to recommend the expression for $k_{2}$ in a wide temperature range, $200-1200 \mathrm{~K}$.
\end{abstract}

Keywords: Oxygen atom, ethene, propene, kinetics, rate coefficient, temperature dependence.

\footnotetext{
*Correspondence to: Yuri Bedjanian: Tel.: +33 238255474, e-mail: yuri.bedjanian@cnrs-orleans.fr

${ }^{\dagger}$ Current address: Mines Douai, SAGE, F-59508, Douai, France.
}

Supporting Information is available in the online issue at www.wileyonlinelibrary.com. 


\section{INTRODUCTION}

Ethene and propene are important intermediates in the oxidation of methane and larger hydrocarbons and, hence, are the key species of the kinetic mechanisms in combustion chemistry [1]. Once formed, they may decompose or react with atoms or radicals (mainly $\mathrm{OH}$, $\mathrm{O}, \mathrm{HO}_{2}$ ). Reaction with oxygen atoms is one of the dominant degradation pathways of the alkenes and is an important step in combustion process particularly affecting the profiles of intermediate species and flame speed. In addition to their importance in combustion, reactions of alkenes with triplet oxygen are of great fundamental interest as reactions proceeding through a complex mechanism with a variety of competitive reaction pathways $[2,3]$.

The theoretical and practical interests to reactions of $\mathrm{O}$-atom with ethene and propene have initiated an extensive research, experimental and theoretical, of these reactive systems over the past few decades [2-20]. Currently, the rate constants of the reactions can be considered as more or less well known (especially for $\mathrm{O}+\mathrm{C}_{2} \mathrm{H}_{4}$ reaction) over a rather wide temperature range extending from atmospheric temperatures to those in combustion [4]. As for the mechanism of these multichannel reactions, the relative importance of different reaction pathways has not yet been fully established. Determination of the primary reaction products and branching ratios for different reaction channels as a function of temperature remains essential for modeling combustion systems.

One of the ongoing projects in our group is focused on a detailed study of the reactions of $\mathrm{O}$ atoms with olefins, in particular regarding the products of these multichannel reactions. This work, being a first step of the investigation, deals with the measurements of the rate constants of the reactions (1) and (2) over an extended temperature range, $230-900 \mathrm{~K}$ :

$$
\begin{aligned}
& \mathrm{O}+\mathrm{C}_{2} \mathrm{H}_{4} \rightarrow \text { products } \\
& \mathrm{O}+\mathrm{C}_{3} \mathrm{H}_{6} \rightarrow \text { products }
\end{aligned}
$$

One of the objectives of the study was to test the experimental approach for detection by mass spectrometry with electron impact ionization of low concentrations of oxygen atoms via their chemical conversion to $\mathrm{BrO}$ radicals. For this purpose, the $\mathrm{O}+\mathrm{C}_{2} \mathrm{H}_{4}$ reaction with well-known rate constant was chosen as a reference one. As for the reaction of $\mathrm{O}$ atom with propene, the existing kinetic data are scattered by a factor of 1.4-1.7 in the temperature range covered by previous studies $(198-1215 \mathrm{~K})[4]$. 


\section{EXPERIMENTAL}

Experiments were carried out in a discharge flow reactor using a modulated molecular beam mass spectrometer with electron impact ionization as the detection method. Two flow reactors were used in the present work. The first one, used at low temperatures $(230-313 \mathrm{~K})$, consisted of a Pyrex tube ( $45 \mathrm{~cm}$ length and $2.4 \mathrm{~cm}$ i.d.) with a jacket for the thermostated liquid circulation (water or ethanol) [21]. The walls of the reactor as well as of the movable injector of $\mathrm{O}$ atoms were coated with halocarbon wax (HW) in order to minimize their heterogeneous loss. The second flow reactor, operating at high temperatures $(\mathrm{T}=298-902$ $\mathrm{K})$, consisted of an electrically heated Quartz tube $(45 \mathrm{~cm}$ length and $2.4 \mathrm{~cm}$ i.d.) with watercooled extremities (Fig. 1) [22]. Temperature in the reactor was measured with a $K$-type thermocouple positioned in the middle of the reactor in contact with its outer surface. Temperature gradients along the flow tube measured with a thermocouple inserted in the reactor through the movable injector was found to be less than $1 \%$ [22].

Oxygen atoms were generated from the microwave discharge in $\mathrm{O}_{2} / \mathrm{He}$ mixtures. Two methods were used for the detection of oxygen atoms. At high concentrations of $\mathrm{O}$ atoms (experiments in excess of $\mathrm{O}$ atoms over $\mathrm{C}_{2} \mathrm{H}_{4}$ or $\mathrm{C}_{3} \mathrm{H}_{6}$ ), they were detected at their parent peak at $\mathrm{m} / \mathrm{z}=16\left(\mathrm{O}^{+}\right)$. The absolute concentrations of the atoms were determined from the fraction of $\mathrm{O}_{2}$ dissociated in the microwave discharge $\left(\Delta\left[\mathrm{O}_{2}\right]=2[\mathrm{O}]\right)$. At low concentrations of oxygen atoms (experiments in excess of alkenes over oxygen atoms), another method for their detection was preferred to the direct one at $\mathrm{m} / \mathrm{z}=16$ due to significant residual signal at this mass. $\mathrm{Br}_{2}$ was added at the end of the reactor through inlet 4 (located $6 \mathrm{~cm}$ upstream of the sampling cone) in order to transform $\mathrm{O}$ atoms to $\mathrm{BrO}$ detected at $\mathrm{m} / \mathrm{z}=95 / 97$ as $\mathrm{BrO}^{+}$:

$$
\begin{aligned}
& \mathrm{O}+\mathrm{Br}_{2} \rightarrow \mathrm{BrO}+\mathrm{Br} \\
& k_{3}=(1.4-2) \times 10^{-11} \mathrm{~cm}^{3} \text { molecule } \mathrm{s}^{-1}(\mathrm{~T}=300 \mathrm{~K})[23,24]
\end{aligned}
$$

The used concentrations of $\mathrm{Br}_{2}\left(\sim 5 \times 10^{13}\right.$ molecule $\left.\mathrm{cm}^{-3}\right)$ were high enough to insure rapid scavenging of oxygen atoms. The possible impact of the recombination reaction of $\mathrm{BrO}$ radicals (4) can be considered as negligible due to relatively low concentrations of $\mathrm{BrO}$ (initial concentration of oxygen atoms was $\leq 4 \times 10^{11}$ molecule $\mathrm{cm}^{-3}$ ):

$$
\begin{aligned}
& \mathrm{BrO}+\mathrm{BrO} \rightarrow \text { products } \\
& k_{4}=1.6 \times 10^{-12} \exp (210 / \mathrm{T}) \mathrm{cm}^{3} \text { molecule }^{-1} \mathrm{~s}^{-1} \text { over } \mathrm{T}=230-390 \mathrm{~K}[25] .
\end{aligned}
$$


Reactions of $\mathrm{BrO}$ with $\mathrm{C}_{2} \mathrm{H}_{4}$ and $\mathrm{C}_{3} \mathrm{H}_{6}$ (present in the reactor in high concentrations, Tables I and II) also have little effect on [BrO], considering the upper limits of the rate constant of these reactions determined in the present study:

$$
\begin{aligned}
& \mathrm{BrO}+\mathrm{C}_{2} \mathrm{H}_{4} \rightarrow \text { products } \\
& k_{5} \leq 4.5 \times 10^{-16} \mathrm{~cm}^{3} \text { molecule } \mathrm{s}^{-1} \text { at } \mathrm{T}=299 \mathrm{~K}, \\
& \mathrm{BrO}+\mathrm{C}_{3} \mathrm{H}_{6} \rightarrow \quad \text { products } \\
& k_{6} \leq 7.0 \times 10^{-15} \mathrm{~cm}^{3} \text { molecule } \mathrm{s}^{-1} \text { at } \mathrm{T}=299 \mathrm{~K} .
\end{aligned}
$$

The possible impact of the reactions of $\mathrm{BrO}$ with multiple primary product-radicals of reaction (1) also appears to be insignificant considering (i) low initial concentrations of oxygen atoms used in kinetic experiments and (ii) expected rapid trapping of the radicals in their reactions with $\mathrm{Br}_{2}$.

Absolute calibration of $\mathrm{BrO}$ signals was realized by chemical conversion of $\mathrm{BrO}$ to $\mathrm{NO}_{2}$ through reaction (7) in excess of $\mathrm{NO}$ (inlet 4) with subsequent detection of $\mathrm{NO}_{2}$ formed $\left([\mathrm{BrO}]_{0}=\left[\mathrm{NO}_{2}\right]_{\text {formed }}\right)$ :

$$
\begin{aligned}
& \mathrm{BrO}+\mathrm{NO} \rightarrow \mathrm{Br}+\mathrm{NO}_{2} \\
& k_{7}=8.7 \times 10^{-12} \exp (260 / \mathrm{T}) \mathrm{cm}^{3} \text { molecule } \mathrm{s}^{-1} \text { over } \mathrm{T}=220-430 \mathrm{~K}[25] .
\end{aligned}
$$

In this case, $\mathrm{BrO}$ was formed through reaction (3) in the movable injector or in the reactor, $\mathrm{Br}_{2}$ being added through inlet 2 or 3 , respectively. The absolute concentrations of $\mathrm{NO}_{2}$ as well as of other stable species $\left(\mathrm{Br}_{2}, \mathrm{C}_{2} \mathrm{H}_{4}, \mathrm{C}_{3} \mathrm{H}_{6}\right)$ in the reactor were calculated from their flow rates obtained from the measurements of the pressure drop of their mixtures in He stored in calibrated volume flasks.

All species, except ethene, were detected by mass spectrometer at their parent peaks: $m / z=42$ (propene, $\left.\mathrm{C}_{3} \mathrm{H}_{6}{ }^{+}\right), 160\left(\mathrm{Br}_{2}^{+}\right), 95 / 97\left(\mathrm{BrO}^{+}\right), 46\left(\mathrm{NO}_{2}{ }^{+}\right), \mathrm{C}_{2} \mathrm{H}_{4}$ was monitored at its fragment peak $m / z=26\left(\mathrm{C}_{2} \mathrm{H}_{2}{ }^{+}\right)$in order to avoid the important contribution at $\mathrm{m} / \mathrm{z}=28$ of $\mathrm{N}_{2}$ traces present in the reactor.

\section{RESULTS AND DISCUSSION}

\section{Rate Constants of Reactions (1) and (2).}

The rate constants of the title reactions were determined under pseudo-first order conditions either from kinetics of $\mathrm{O}$-atom consumption in excess of alkene or from alkene decays monitored in excess of oxygen atoms. In experiments carried out in excess of alkene, the 
initial concentration of $\mathrm{O}$ atoms was between 2 and $4 \times 10^{11}$ molecule $\mathrm{cm}^{-3}$, the concentrations of olefins are shown in Tables I and II. The flow velocity in the reactor was in the range (1070-2650) and (1158-3500) $\mathrm{cm} \mathrm{s}^{-1}$ in the study of the reactions (1) and (2), respectively. The concentrations of $\mathrm{O}$ and ethene/propene were simultaneously measured as a function of reaction time. As a rule, the consumption of alkenes was negligible as a result of their high excess over oxygen atoms. Examples of O-atom decays observed at different concentrations of ethene and propene are shown in Fig. 2 and 1S (Supporting Information), respectively. Figure 3 shows the pseudo-first order rate constant, $k_{1}{ }^{\prime}=k_{1}\left[\mathrm{C}_{2} \mathrm{H}_{4}\right]+k_{\mathrm{w}}$, as a function of the concentration of ethene. $k_{\mathrm{w}}$ represents the rate of $\mathrm{O}$ decay in the absence of $\mathrm{C}_{2} \mathrm{H}_{4}$ in the reactor and was measured in separate experiments. Example of the pseudo-first order plots observed in reaction $\mathrm{O}+\mathrm{C}_{3} \mathrm{H}_{6}$ is shown in Fig. $2 \mathrm{~S}$ (Supporting Information). All the measured values of $k_{1}{ }^{\prime}$ and $k_{2}{ }^{\prime}$ were corrected for axial and radial diffusion [26] of oxygen atoms. The diffusion coefficient of $\mathrm{O}$ in He was calculated using $D_{0}=770$ Torr $\mathrm{cm}^{2} \mathrm{~s}^{-1}$ at $\mathrm{T}=298 \mathrm{~K}$ [27] and assuming $\mathrm{T}^{1.75}$-dependence on temperature. Corrections were generally less than $10 \%$, and only in a few kinetic runs they were higher, up to $30 \%$. The slopes of the straight lines in Fig. 3 and $2 \mathrm{~S}$ give the values of $k_{1}$ and $k_{2}$ at respective temperatures. The intercepts were in the range $(25 \pm 15) \mathrm{s}^{-1}$ without a marked dependence on temperature and were always a bit higher than the corresponding $\mathrm{O}$ loss rate measured in the absence of alkene in the reactor.

All the results obtained for $k_{1}$ and $k_{2}$ at different temperatures are shown in Table I and Fig. 4 (black filled circles) and Table II and Fig. 5 (black filled circles), respectively. The combined uncertainty on the measurements of the rate constants was estimated to be nearly $15 \%$, including statistical error (within a few percent) and those on the measurements of the flows $(5 \%)$, pressure $(3 \%)$, temperature $(1 \%)$ and the absolute concentration of alkenes $(\leq$ $10 \%$ ). One can note good agreement between the rate constants determined in low (covered with halocarbon wax) and high temperature (quartz) reactors under close experimental conditions, allowing one to relate the measurements at high and low temperatures.

\section{Secondary Reactions.}

Reactions (1) and (2) are multichannel reactions leading to formation of numerous chemically active products, for instance, $\mathrm{CH}_{3}, \mathrm{C}_{2} \mathrm{H}_{5}, \mathrm{HCO}, \mathrm{CH}_{2}$ radicals [2,3], which can react with oxygen atoms in secondary reactions. Indeed, the reactions of $\mathrm{O}$-atoms with these species are known to be very rapid, with a rate constant of $\sim 10^{-10} \mathrm{~cm}^{3}$ molecule $\mathrm{s}^{-1}$ in the temperature range of this study [4]. 
In order to check for the possible impact on the measurements of $k_{2}$ of the secondary chemistry we have carried out a series of experiments, where the rate of reaction (2) was measured as a function of initial concentration of oxygen atoms. Experiments were carried out with a fixed concentration of $\mathrm{C}_{3} \mathrm{H}_{6}\left(4.7 \times 10^{13}\right.$ molecule $\left.\mathrm{cm}^{-3}\right)$ and $\mathrm{O}$-atom concentration varied in the range $(0.2-3.9) \times 10^{12}$ molecule $\mathrm{cm}^{-3}$. The pseudo-first order rate constant $k_{2}{ }^{\prime}$ was observed to be independent of the initial concentration of $\mathrm{O}$ for $[\mathrm{O}]_{0} \leq 0.8 \times 10^{12}$ molecule $\mathrm{cm}^{-3}$ and to increase at higher initial concentrations of oxygen atoms, indicating that the contribution of the secondary chemistry to $\mathrm{O}$-atom loss under experimental conditions of the study $\left([\mathrm{O}]_{0}=(0.2-0.4) \times 10^{12}\right.$ molecule $\left.\mathrm{cm}^{-3}\right)$ is negligible.

Although in kinetic experiments relatively low concentrations of oxygen atoms were used $\left((2-4) \times 10^{11}\right.$ molecule $\left.\mathrm{cm}^{-3}\right)$ and no appreciable effect on $k_{1}$ and $k_{2}$ was observed when $[\mathrm{O}]_{0}$ was varied in this range, we have carried out another series of test-experiments where the reaction rate constant was measured from decays of $\mathrm{C}_{2} \mathrm{H}_{4}\left(\mathrm{C}_{3} \mathrm{H}_{6}\right)$ in excess of O-atoms, i.e. under conditions where secondary chemistry can be excluded. In fact, the only likely reaction which can contribute to secondary $\mathrm{C}_{2} \mathrm{H}_{4}\left(\mathrm{C}_{3} \mathrm{H}_{6}\right)$ consumption is the reaction with hydrogen atoms, which are among the products of reactions (1) and (2) [2,3]:

$$
\begin{array}{lll}
\mathrm{H}+\mathrm{C}_{2} \mathrm{H}_{4} & \rightarrow & \mathrm{H}_{2}+\mathrm{C}_{2} \mathrm{H}_{3} \\
\mathrm{H}+\mathrm{C}_{2} \mathrm{H}_{4}(+\mathrm{M}) & \rightarrow & \mathrm{C}_{2} \mathrm{H}_{5}(+\mathrm{M}) \\
\mathrm{H}+\mathrm{C}_{3} \mathrm{H}_{6} & \rightarrow & \mathrm{H}_{2}+\mathrm{C}_{3} \mathrm{H}_{5} \\
\mathrm{H}+\mathrm{C}_{3} \mathrm{H}_{6}(+\mathrm{M}) & \rightarrow & \mathrm{n}^{-} \mathrm{C}_{3} \mathrm{H}_{7}(+\mathrm{M}) \\
\mathrm{H}+\mathrm{C}_{3} \mathrm{H}_{6}(+\mathrm{M}) & \rightarrow & \text { iso- }_{3} \mathrm{H}_{7}(+\mathrm{M})
\end{array}
$$

Under experimental conditions of the present study $(\mathrm{T}=230-900 \mathrm{~K})$ both reactions, $(8)$ and (9), are dominated by the addition channels with the rate constants $k_{8 \mathrm{~b}} \approx 10^{-13}$ [4], $k_{9 \mathrm{~b}}=$ $4.15 \times 10^{-13} \mathrm{~T}^{0.51} \exp (-1323 / \mathrm{T})$ and $k_{9 \mathrm{c}}=7.04 \times 10^{-13} \mathrm{~T}^{0.51} \exp (-622 / \mathrm{T}) \mathrm{cm}^{3}$ molecule $^{-1} \mathrm{~s}^{-1} \quad$ [28]. Experiments were carried out with initial concentration of $\mathrm{C}_{2} \mathrm{H}_{4} \leq 10^{12}$ molecule $\mathrm{cm}^{-3}$; accordingly the impact of reactions (8) and (9) could be neglected (under the temperatures of the experiments).

The measurements of $k_{1}$ from decays of $\mathrm{C}_{2} \mathrm{H}_{4}$ in excess of $\mathrm{O}$-atoms were carried out at three temperatures: 375,522 and $623 \mathrm{~K}$. The respective initial concentrations of oxygen atoms are presented in Table I. Flow velocities in the reactor were in the range 1140-1840 $\mathrm{cm} \mathrm{s}^{-1}$. Consumption of the excess reactant, O-atom (due to its heterogeneous loss, reaction with $\mathrm{C}_{2} \mathrm{H}_{4}$ and secondary reactions with products of reaction (1)), was observed to be lower than $10 \%$ and mean concentration of the oxygen atoms along the reaction zone was used in the 
calculations of $k_{1}$. The pseudo-first order plots measured from decays of $\mathrm{C}_{2} \mathrm{H}_{4}$ in excess of $\mathrm{O}$ are shown in Fig. 6. The pseudo-first order rate constants, $k_{1}{ }^{\prime}=-\mathrm{d}\left(\ln \left[\mathrm{C}_{2} \mathrm{H}_{4}\right]\right) / \mathrm{dt}=k_{1}[\mathrm{O}]$, were corrected for the axial and radial diffusion of $\mathrm{C}_{2} \mathrm{H}_{4}$ [10]. The diffusion coefficient of $\mathrm{C}_{2} \mathrm{H}_{4}$ in He, $D_{0}=375 \times(T / 298)^{1.75}$ Torr $\mathrm{cm}^{-2} \mathrm{~s}^{-1}$, was calculated using Fuller's method [29]. The corrections on the measured values of $k_{1}{ }^{\prime}$ were less than $6 \%$. The final values of $k_{1}$ obtained from the linear through origin fit to the experimental data (Fig. 6) are presented in Table I and in Fig. 4 (black filled squares). Similar experiments were conducted for the reaction $\mathrm{O}_{+} \mathrm{C}_{3} \mathrm{H}_{6}$ at two temperatures, $\mathrm{T}=243$ and $265 \mathrm{~K}$. Example of kinetic runs of $\mathrm{C}_{3} \mathrm{H}_{6}$ consumption in excess of O-atoms are shown in Fig. 3S (Supporting Information). The pseudo-first order plots observed at $\mathrm{T}=243$ and $265 \mathrm{~K}$ are demonstrated in Fig. 4S (Supporting Information). The final data for $k_{2}$ from these experiments are shown in Table II and in Figure 5 (black filled squares). One can note an excellent agreement between the values of $k_{1}$ and $k_{2}$ obtained in the present study using two different approaches, which seems to exclude any noticeable impact of the secondary reactions.

\section{Comparison with Previous Data.}

Figure 4 summarizes the results of temperature dependent studies [5-17] of the rate constant of reaction (1). One can note good agreement of the results reported by almost all the research groups. The rate constant data from this study can be represented as three parameter expression (in $\mathrm{cm}^{3}$ molecule $\mathrm{s}^{-1}$, black line in Figure 4):

$$
k_{1}=8.64 \times 10^{-17} \mathrm{~T}^{1.70} \exp (-206 / \mathrm{T}) \text { at } \mathrm{T}=(230-902) \mathrm{K} .
$$

The dashed lines in Fig. 4 correspond to $\pm 20 \%$ deviation from this expression showing that practically all existing data fall into this range. Above expression is in good agreement with the current recommendation for $k_{1}$ (red continuous line in Fig. 4):

$$
k_{1}=2.25 \times 10^{-17} \mathrm{~T}^{1.88} \exp (-92 / \mathrm{T}) \mathrm{cm}^{3} \text { molecule } \mathrm{s}^{-1} \text { at } \mathrm{T}=(220-2000) \mathrm{K} \text { [4]. }
$$

The two expressions give practically identical values for $k_{1}$ at $\mathrm{T} \geq 300 \mathrm{~K}$ and slightly diverge at low temperatures. The good agreement of the present data for $k_{1}$ with those from previous studies seems to indicate the correctness of the approach employed in the present study for the detection of small concentration of oxygen atoms.

The results of our measurements of $k_{2}$ are shown in Fig. 5. together with those from previous studies $[5,6,14,15,18-20]$. Three parameter fit to the present data (black continuous line) provides the following expression for the rate constant of $\mathrm{O}+\mathrm{C}_{3} \mathrm{H}_{6}$ reaction:

$$
k_{2}=3.65 \times 10^{-18} \mathrm{~T}^{2.20} \exp (455 / \mathrm{T}) \mathrm{cm}^{3} \text { molecule }^{-1} \mathrm{~s}^{-1} \text { at } \mathrm{T}=(230-900) \mathrm{K} \text {. }
$$


One can note that the most of the previous data (except two earliest studies [5,15]) fall into the area delimited by black dashed lines which correspond to $\pm 20 \%$ deviation from the above expression.

Finally, comparison of the present data with previous work (Fig.4 and 5) seems to show that the expressions obtained for $k_{1}$ and $k_{2}$ in the present study can be recommended for use in the temperature range $195-2300 \mathrm{~K}$ and $200-1200 \mathrm{~K}$, respectively, with conservative $20 \%$ uncertainty. Concerning the mechanism of the reactions (1) and (2), the branching ratios for different reaction pathways of these multichannel reactions, which are of great fundamental and practical interest for combustion modeling, are the subject of our current research.

\section{CONCLUSION}

In this work, using two (low and high temperature) flow reactors, we have measured the rate constants of the reactions of $\mathrm{O}\left({ }^{3} \mathrm{P}\right)$ atoms with ethene and propene over extended temperature range, $230-900 \mathrm{~K}$. The temperature dependence of the rate constant of the reaction of oxygen atoms with ethene was found to be in excellent agreement with multiple previous data for this well-studied reaction that can be considered as a validation of the experimental approach especially regarding the detection of low concentrations of oxygen atoms via their chemical conversion to $\mathrm{BrO}$ radicals. The measurements of the rate constant of the reaction of $\mathrm{O}$ atoms with propene allowed to harmonize the results of previous low and high temperature measurements and to recommend the temperature dependence of the reaction rate constant in a wide temperature range, $200-1200 \mathrm{~K}$.

This study was supported by CAPRYSSES project (ANR-11-LABX-006-01) funded by the French National Research Agency (ANR) through the PIA (Programme d'Investissement d'Avenir). 


\section{BIBLIOGRAPHY}

1. Gardiner, W. C., Jr. Gas-Phase Combustion Chemistry; Springer: New York, 2000.

2. Leonori, F.; Balucani, N.; Nevrly, V.; Bergeat, A.; Falcinelli, S.; Vanuzzo, G.; Casavecchia, P.; Cavallotti, C. J. Phys. Chem. C 2015, 119, 14632-14652.

3. Fu, B.; Han, Y.-C.; Bowman, J. M.; Leonori, F.; Balucani, N.; Angelucci, L.; Occhiogrosso, A.; Petrucci, R.; Casavecchia, P. J. Chem. Phys. 2012, 137, 22 A532.

4. Baulch, D. L.; Bowman, C. T.; Cobos, C. J.; Cox, R. A.; Just, T.; Kerr, J. A.; Pilling, M. J.; Stocker, D.; Troe, J.; Tsang, W.; Walker, R. W.; Warnatz, J. J. Phys. Chem. Ref. Data. 2005, 34, 757-1397.

5. Atkinson, R.; Cvetanović, R. J. J. Chem. Phys. 1972, 56, 432-437.

6. Browarzik, R.; Stuhl, F. J. Phys. Chem. 1984, 88, 6004-6009.

7. Davis, D. D.; Huie, R. E.; Herron, J. T.; Kurylo, M. J.; Braun, W. J. Chem. Phys. 1972, 56, 4868-4876.

8. $\quad$ Elias, L. J. Chem. Phys. 1963, 38, 989-995.

9. Fenimore, C. P.; Jones, G. W. Symp. Int. Combust. 1963, 9, 597-606.

10. Klemm, R. B.; Nesbitt, F. L.; Skolnik, E. G.; Lee, J. H.; Smalley, J. F. J. Phys. Chem. 1987, 91, 1574-1580.

11. Klemm, R. B.; Sutherland, J. W.; Wickramaaratchi, M. A.; Yarwood, G. J. Phys. Chem. 1990, 94, 3354-3357.

12. Mahmud, K.; Marshall, P.; Fontijn, A. J. Phys. Chem. 1987, 91, 1568-1573.

13. Nicovich, J. M.; Ravishankara, A. R. Symp. Int. Combust. 1982, 19, 23-30.

14. Perry, R. A. J. Chem. Phys. 1984, 80, 153-158.

15. Singleton, D. L.; Cvetanovic, R. J. J. Am. Chem. Soc. 1976, 98, 6812-6819.

16. Umemoto, H.; Sugiyama, K.; Tsunashima, S.; Sato, S. Bull. Chem. Soc. Jpn. 1985, 58, 1228-1233.

17. Westenberg, A. A.; deHaas, N. Symp. Int. Combust. 1969, 12, 289-299.

18. Atkinson, R.; Pitts, J. N. J. Chem. Phys. 1977, 67, 38-43.

19. Kurylo, M. J. Chem. Phys. Lett. 1972, 14, 117-120.

20. Mahmud, K.; Fontijn, A. Symp. Int. Combust. 1989, 22, 991-996.

21. Riffault, V.; Bedjanian, Y.; Le Bras, G. J. Phys. Chem. A 2003, 107, 5404-5411.

22. Morin, J.; Romanias, M. N.; Bedjanian, Y. Int. J. Chem. Kinet. 2015, 47, 629-637.

23. Harwood, M. H.; Rowley, D. M.; Cox, R. A.; Jones, R. L. J. Phys. Chem. A 1998, 102, 1790-1802.

24. Nicovich, J. M.; Wine, P. H. Int. J. Chem. Kinet. 1990, 22, 379-397.

25. Atkinson, R.; Baulch, D. L.; Cox, R. A.; Crowley, J. N.; Hampson, R. F.; Hynes, R. G.; Jenkin, M. E.; Rossi, M. J.; Troe, J. Atmos. Chem. Phys. 2007, 7, 981-1191.

26. Kaufman, F. J. Phys. Chem. 1984, 88, 4909-4917.

27. Ivanov, A. V.; Trakhtenberg, S.; Bertram, A. K.; Gershenzon, Y. M.; Molina, M. J. J. Phys. Chem. A 2007, 111, 1632-1637.

28. Curran, H. J. Int. J. Chem. Kinet. 2006, 38, 250-275.

29. Tang, M. J.; Cox, R. A.; Kalberer, M. Atmos. Chem. Phys. 2014, 14, 9233-9247. 


\section{TABLES}

Table I Reaction $\mathrm{O}+\mathrm{C}_{2} \mathrm{H}_{4} \rightarrow$ products: Summary of the Measurements of the Rate Constant

\begin{tabular}{ccccc}
\hline $\mathrm{T}(\mathrm{K})$ & $\begin{array}{c}\text { Number of } \\
\text { Kinetics }\end{array}$ & $\begin{array}{c}\text { [Excess reactant] } \\
\left(10^{14} \text { molecule } \mathrm{cm}^{-3}\right)^{a}\end{array}$ & $\begin{array}{c}k_{1} \\
\left(10^{-12} \mathrm{~cm}^{3} \text { molecule }^{-1} \mathrm{~s}^{-1}\right)^{b}\end{array}$ & $\begin{array}{c}\text { Reactor } \\
\text { surface }^{c}\end{array}$ \\
\hline 230 & 9 & $0.35-7.38$ & 0.37 & $\mathrm{HW}$ \\
240 & 7 & $0.30-3.98$ & 0.43 & $\mathrm{HW}$ \\
265 & 9 & $0.36-4.34$ & 0.52 & $\mathrm{HW}$ \\
300 & 9 & $0.30-4.18$ & 0.71 & $\mathrm{HW}$ \\
339 & 10 & $0.38-8.16$ & 0.95 & $\mathrm{Q}$ \\
375 & 8 & $0.06-0.51$ & 1.12 & $\mathrm{Q}$ \\
409 & 10 & $0.14-2.85$ & 1.38 & $\mathrm{Q}$ \\
425 & 6 & $0.25-1.38$ & 1.59 & $\mathrm{Q}$ \\
493 & 8 & $0.10-1.84$ & 2.11 & $\mathrm{Q}$ \\
522 & 7 & $0.08-0.77$ & 2.39 & $\mathrm{Q}$ \\
579 & 10 & $0.07-1.45$ & 3.11 & $\mathrm{Q}$ \\
623 & 8 & $0.09-0.50$ & 3.41 & $\mathrm{Q}$ \\
673 & 7 & $0.08-1.12$ & 4.23 & $\mathrm{Q}$ \\
776 & 7 & $0.07-1.07$ & 5.42 & $\mathrm{Q}$ \\
829 & 7 & $0.05-0.64$ & 6.18 & $\mathrm{Q}$ \\
902 & 8 & $0.10-1.51$ & 7.20 & $\mathrm{Q}$ \\
\hline
\end{tabular}

${ }^{a}$ Excess reactant: oxygen atom at $\mathrm{T}=375,522$ and $623 \mathrm{~K}, \mathrm{C}_{2} \mathrm{H}_{4}$ at all other temperatures

${ }^{b}$ typical uncertainty on $k_{1}$ is nearly $15 \%$

${ }^{c}$ HW: halocarbon wax, Q: quartz 
Table II Reaction $\mathrm{O}+\mathrm{C}_{3} \mathrm{H}_{6} \rightarrow$ products: Summary of the Measurements of the Rate Constant

\begin{tabular}{ccccc}
\hline $\mathrm{T}(\mathrm{K})$ & $\begin{array}{c}\text { Number of } \\
\text { Kinetics }\end{array}$ & $\begin{array}{c}\text { [Excess reactant] } \\
\left(10^{13} \text { molecule } \mathrm{cm}^{-3}\right)^{a}\end{array}$ & $\begin{array}{c}k_{2} \\
\left(10^{-12} \mathrm{~cm}^{3} \mathrm{molecule}^{-1} \mathrm{~s}^{-1}\right)^{b}\end{array}$ & $\begin{array}{c}\text { Reactor } \\
\text { surface }^{c}\end{array}$ \\
\hline 230 & 7 & $0.91-6.30$ & 4.11 & HW \\
243 & 8 & $0.33-5.27$ & 4.01 & HW \\
253 & 7 & $0.68-10.2$ & 4.23 & HW \\
265 & 8 & $0.24-4.66$ & 4.38 & HW \\
278 & 8 & $0.34-6.85$ & 4.57 & HW \\
298 & 16 & $0.11-5.64$ & 4.65 & $\mathrm{Q}$ \\
313 & 8 & $0.22-9.81$ & 4.91 & HW \\
329 & 8 & $0.19-8.16$ & 5.03 & $\mathrm{Q}$ \\
373 & 15 & $0.16-6.89$ & 5.51 & $\mathrm{Q}$ \\
422 & 9 & $0.15-7.28$ & 6.61 & $\mathrm{Q}$ \\
483 & 9 & $0.15-6.03$ & 7.24 & $\mathrm{Q}$ \\
577 & 9 & $0.15-6.46$ & 9.47 & $\mathrm{Q}$ \\
711 & 8 & $0.14-6.05$ & 12.9 & $\mathrm{Q}$ \\
900 & 8 & $0.09-4.55$ & 19.0 & $\mathrm{Q}$ \\
\hline
\end{tabular}

${ }^{a}$ excess reactant: oxygen atom at $\mathrm{T}=243$ and $265 \mathrm{~K}, \mathrm{C}_{3} \mathrm{H}_{6}$ at all other temperatures

${ }^{b}$ typical uncertainty on $k_{1}$ is nearly $15 \%$

${ }^{c} \mathrm{HW}$ : halocarbon wax, Q: quartz 


\section{FIGURE CAPTIONS}

Figure 1 Diagram of the flow reactor.

Figure 2 Reaction $\mathrm{O}+\mathrm{C}_{2} \mathrm{H}_{4}$ : example of the exponential decays of $\mathrm{O}$ atoms in excess of ethene at $\mathrm{T}=230 \mathrm{~K}$.

Figure 3 Reaction $\mathrm{O}+\mathrm{C}_{2} \mathrm{H}_{4}$ : example of pseudo-first order plots obtained from $\mathrm{O}$ decays in excess of $\mathrm{C}_{2} \mathrm{H}_{4}$ at different temperatures.

Figure 4 Reaction $\mathrm{O}+\mathrm{C}_{2} \mathrm{H}_{4}$ : summary of the measurements of the temperature dependence of the rate constant. Error bars correspond to $15 \%$ uncertainty on $k_{1}$.

Figure 5 Reaction $\mathrm{O}+\mathrm{C}_{3} \mathrm{H}_{6}$ : summary of the measurements of the temperature dependence of the rate constant. Error bars correspond to $15 \%$ uncertainty on $k_{2}$.

Figure 6 Reaction $\mathrm{O}+\mathrm{C}_{2} \mathrm{H}_{4}$ : example of pseudo-first order plots obtained from decays of $\mathrm{C}_{2} \mathrm{H}_{4}$ in excess of oxygen atoms at different temperatures. 


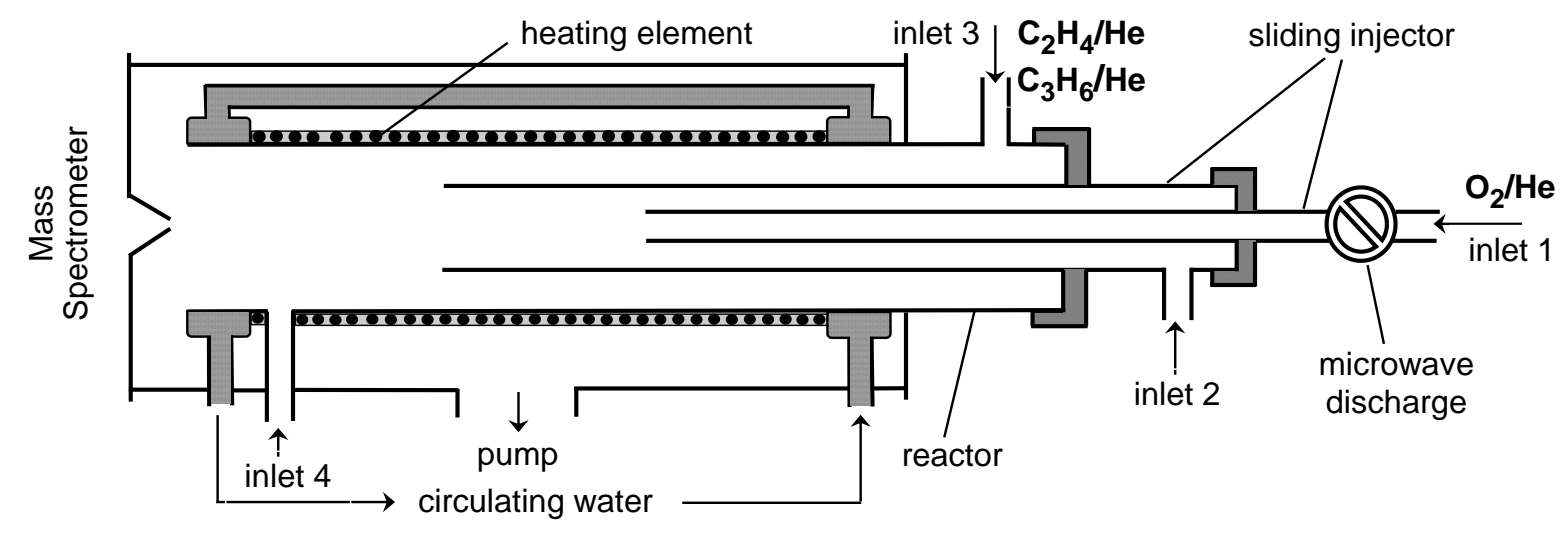

Figure 1

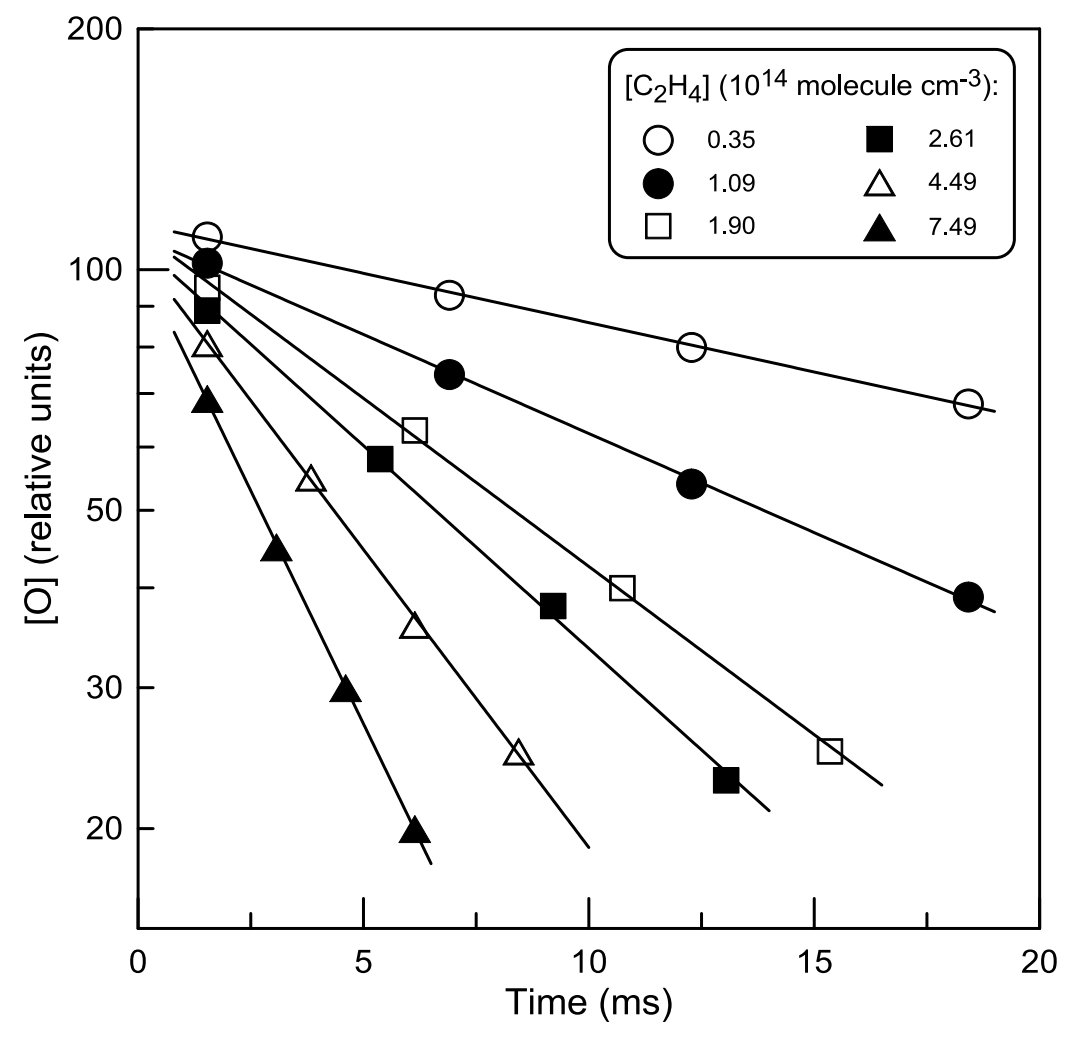

Figure 2 


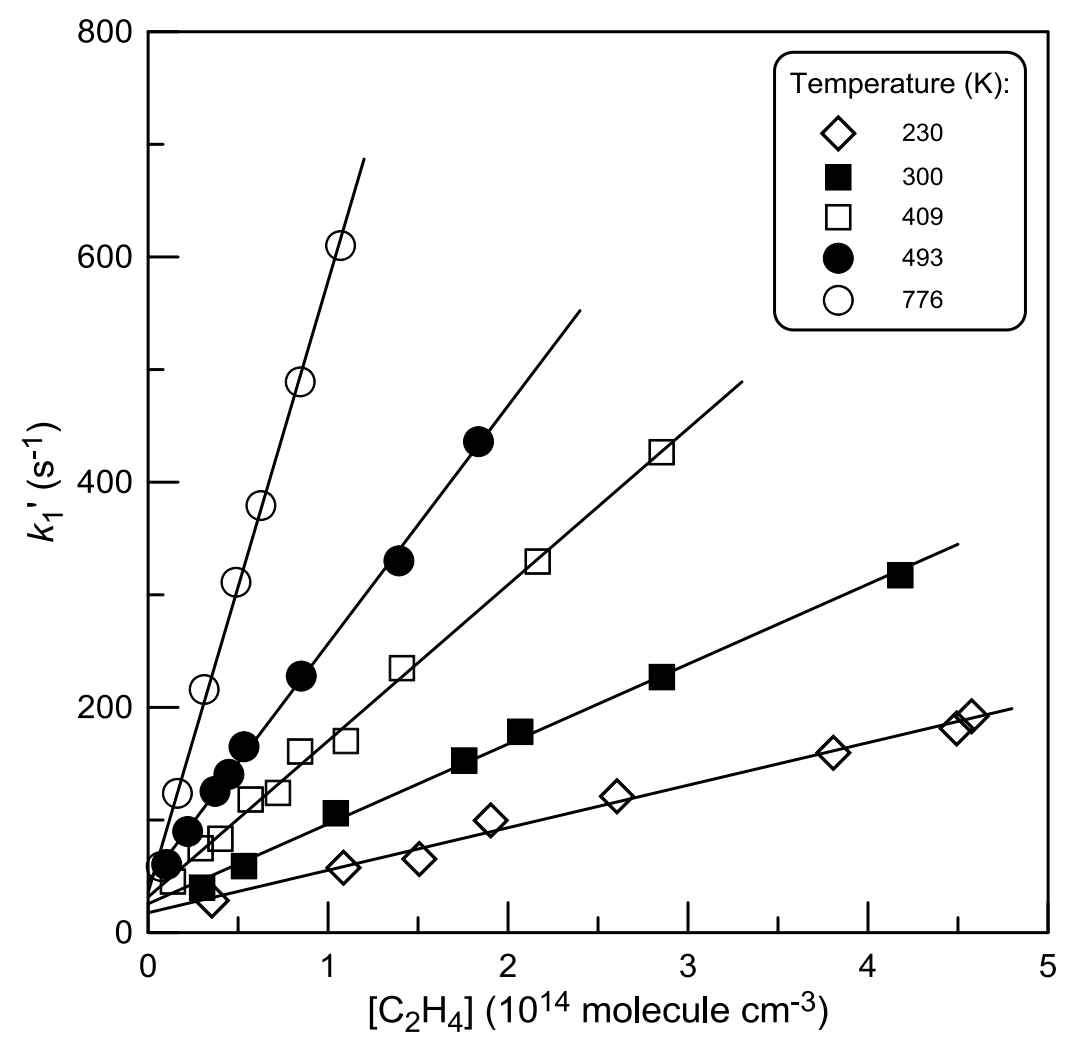

Figure 3

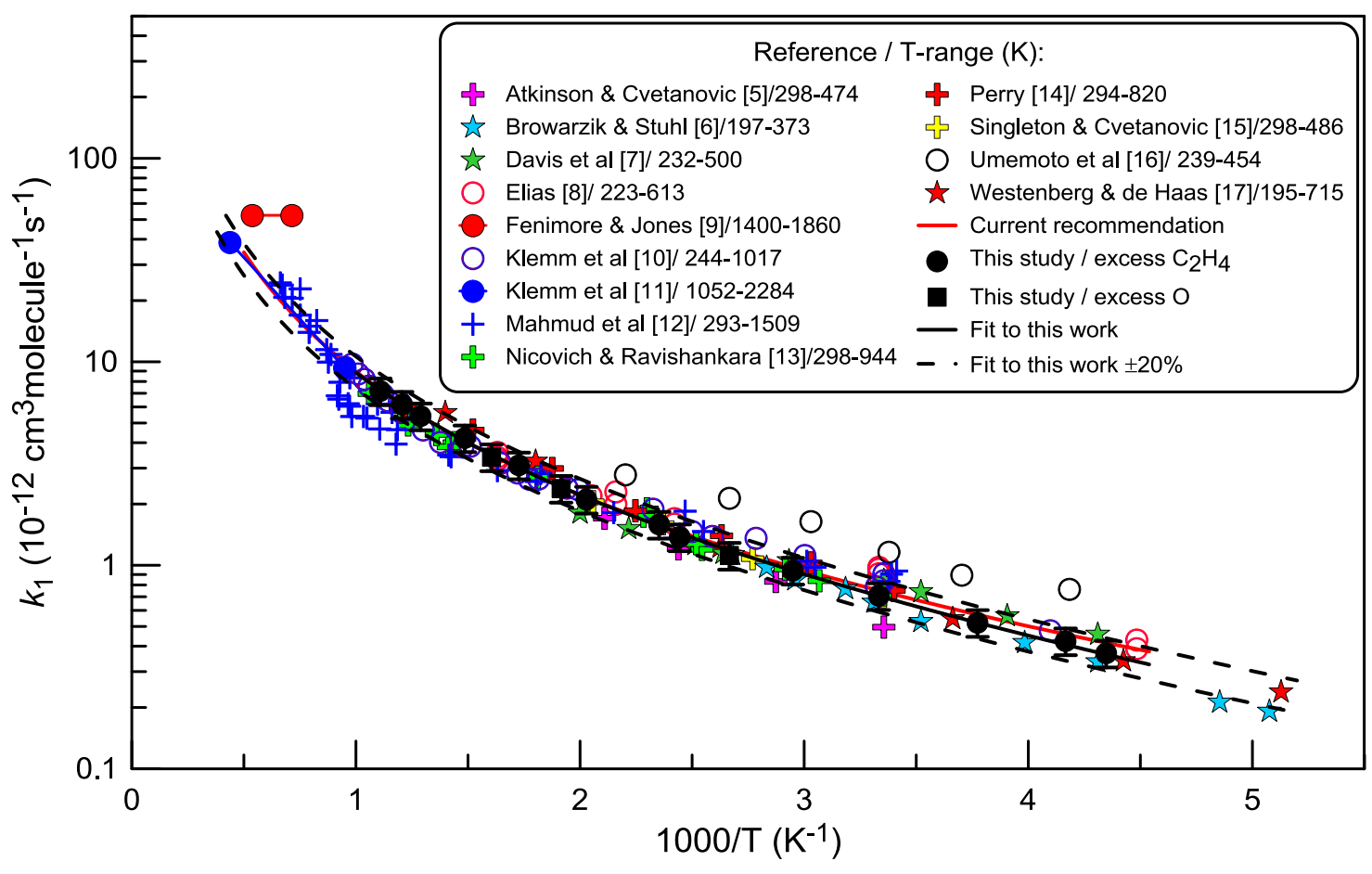

Figure 4 


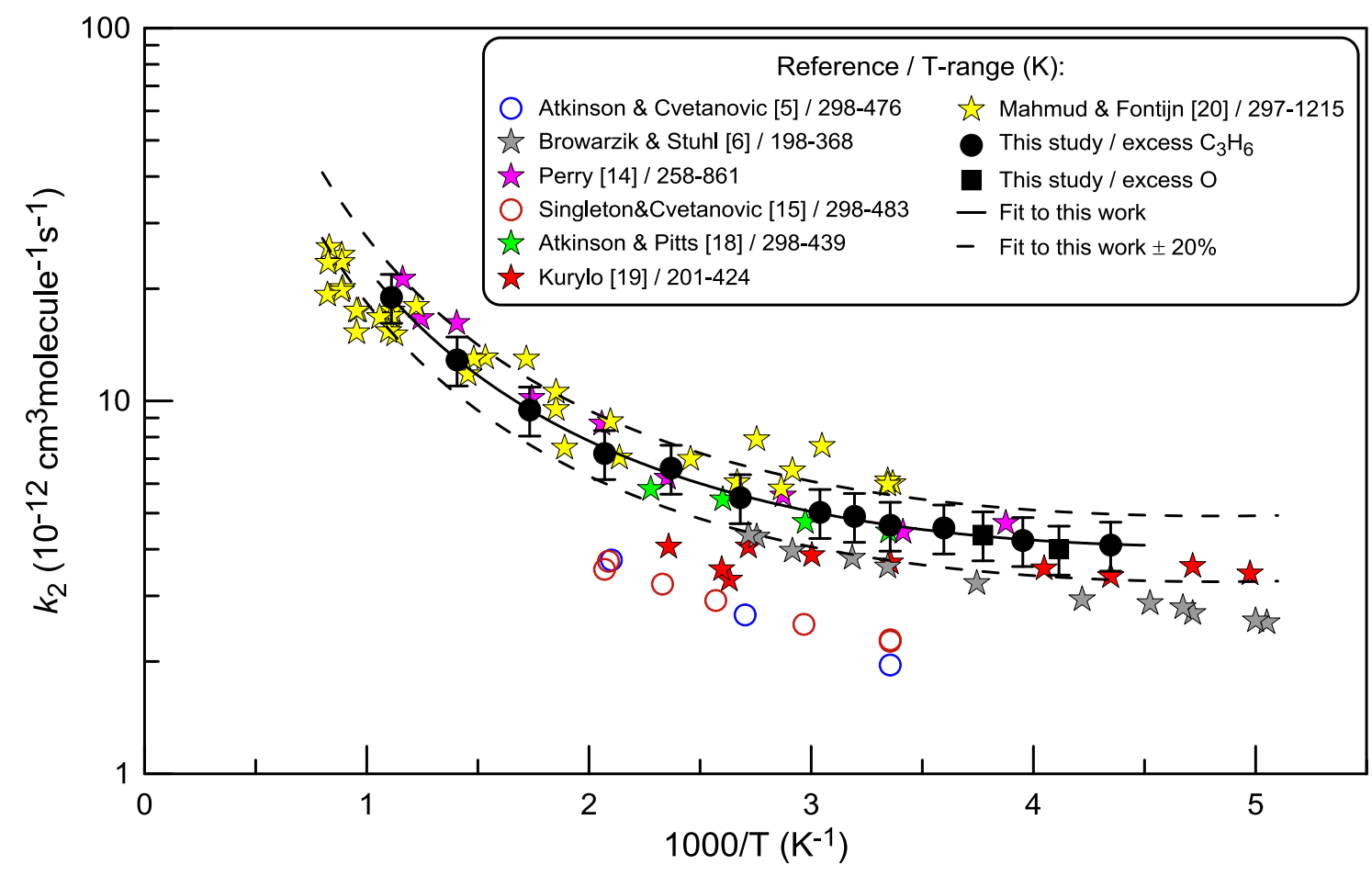

Figure 5

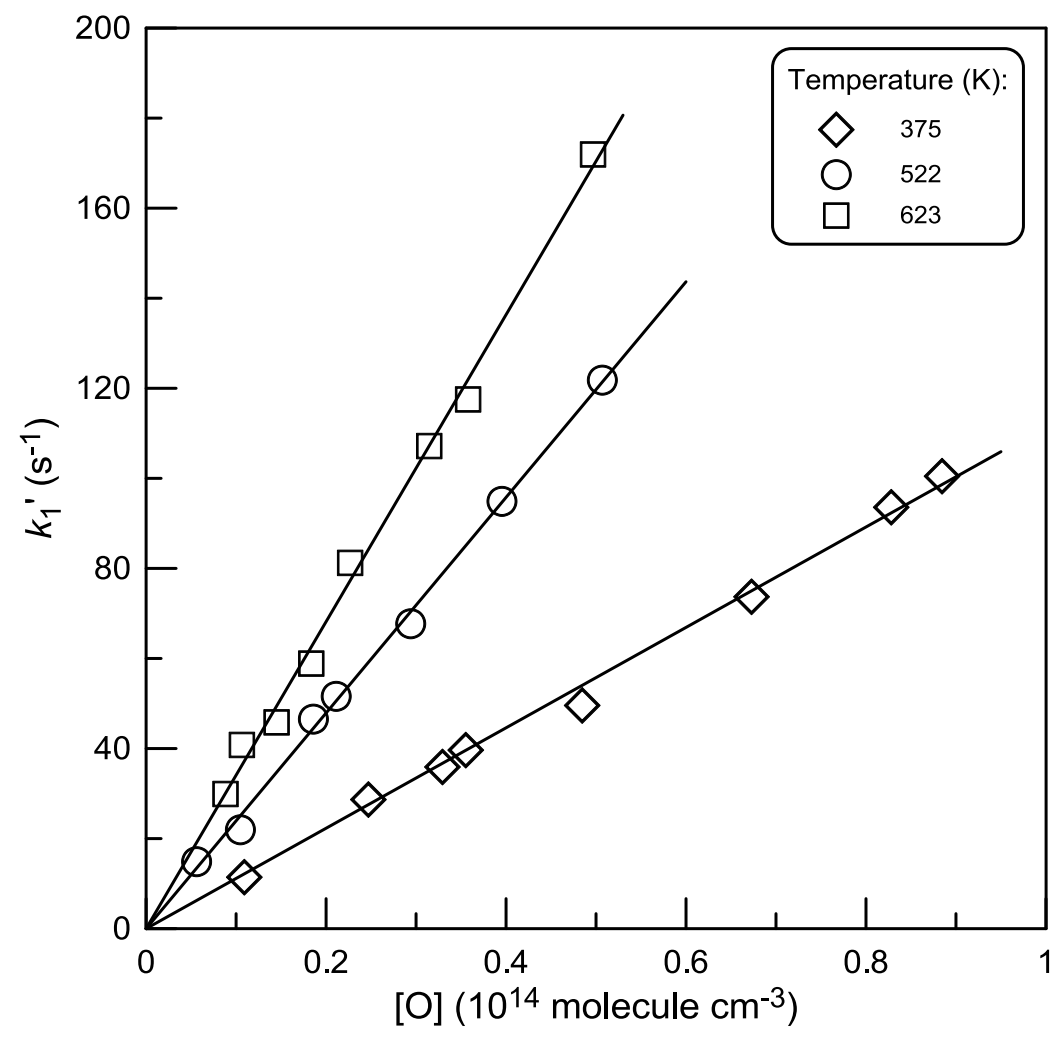

Figure 6 